\title{
Following the Tracks of a Myth
}

\author{
Edvardas GUDAVIČIUS
}

\section{"An elephant? I didn't see any elephant" Soviet folklore*}

For more than a decade an idea has been prevalent in Belorussia claiming that the real "Lithuanians" were none other than Belorussians, who founded the Grand Duchy of Lithuania and incorporated the people of the modern Lithuanian Republic into that entity $^{1}$. This idea has its origins in the early years of the century and is propagated today most enthusiastically by M.Ermalovich. The present study, which borrows its title from Ermalovich's book, aims to discuss the idea ${ }^{2}$. Ermalovich regards as mythical the fact that Lithuanians (lietuviai) are still called "Lithuanian" rather than "Lietuvians" (lietuvisai). In other words, the axioms of the proof system have been altered. Let us briefly outline how this change came about.

The book under review has seven chapters, the first of which describes how disputes between sixteenth-century Russian and Lithuanian historians distorted history by inventing the idea that Lithuania annexed Belorussia ${ }^{3}$. This definitive chapter sets out the alternative axiom. The proof begins in the second chapter, but these theorems are not applied as yet to the derivation of the axiom; it only says that during the twelfth and the first half of the thirteenth centuries the duchies which existed in the territory of modern Belorussia grew in strength and size ${ }^{4}$. Chapter three raises the question "where was the Lithuania which the chronicles describe?" as an axiom ${ }^{5}$. Thus, in the seven-chapter-scheme the original axiom is disguised as a theorem and transferred to a point further along on the proof sequence ${ }^{6}$. In this way the author attempts to raise ideas which he has already defined as his original concept and compels potential opponents not

* According to a Soviet anecdote, an American, a Frenchman and a Russian were asked to write on the subject of elephants. The American produced an essay on elephants and the economy, the Frenchman discussed pachyderm love life, the Russian remarked, on being questioned after the deadline set for the article: "an elephant? was there an elephant?"

${ }^{1}$ V. Nasevich, Pachatki vialikaga kniastva litouskaga. Padzei $i$ asobi, Minsk,1993, 5-6.

${ }^{2}$ M. Ermalovich, Pa sliadakh adnago mifa (Minsk,1989, ${ }^{2} 1991$ ).

${ }^{3}$ Ermalovich, op. cit., 1991, 4-8.

${ }^{4}$ Ibid., 9-19.

${ }^{5}$ Ibid., 20-34.

${ }^{6}$ Ibid., 96. 
to use "denied" axioms ${ }^{7}$. The remaining chapters explain how, in the mid-thirteenth century Mindaugas, a Slavonic or slavonicised scion of "Chronicle" or "Ancient" Lithuania went to Slavonic Novgorodok whence he conquered the territory of modern Lithuania and gave those lands the name of "Lithuania". In this fashion Ermalovich defends his arguments with a psychological "barrier section". Thus laid out, the game requires the proof of the Lithuanianness of the Lithuanians and of the Lithuania of the records, although this, as soon as their slavonicity was proved, should be a resulting conclusion which has been turned into a preliminary axiom. To put it mildly, logic calls this method an alteration in the theme of the proof. The author himself senses the artificiality of this construct when he realises that he has underestimated the sources as a whole. Therefore he finds it necessary to declare the Lithuanians recorded by Henricus Lettus "an obscure tribe" .

In order to evaluate Ermalovich's arguments, we might survey how he understands the following matters which he raises as important questions:

1. What was the name of the newly defined Lietuvian, or BalticLithuanian tribe that is said to have inhabited the territory of the modern Lithuanian Republic?

2. How and where did "Primary", "Chronicle" or "Ancient" Lithuania originate? How did it give the historic name of "Lithuania" to the Belorussians and the state they founded (the Grand Duchy of Lithuania) and imposed on the ancestors of the modern Lithuanians?

3. How and why did this "Ancient" Lithuania become Slavonic?

4. Who was Mindaugas?

5. Who was Vaišelga?

1 .

Ermalovich defines the Lietuvians or ancestors of the Lithuanians as inhabitants of "Baltic Lithuanian lands" or "Aukštaitians" and "Žemaitians"10. If these Balts did not call themselves Lithuanians, then sources for what is more-or-less the territory of the modern Lithuanian Republic should not make reference to Lithuanians. However this is not the case:

a) The account of the 1219 Lithuano-Galich Treaty very clearly shows that the Žemaitians and Deltuva were constituent parts of

${ }^{7}$ Ermalovich, op. cit., 1989, 3 - L. Alekseev's preface to this edition.

${ }^{8}$ M. Ermalovich, Starazhytnaia Belarus. Polatski i novagarodski peryiady, Minsk,1990, 269. See below nn. 19-27.

9 "Z razgledzhanaga bachna, shto baltska-litouskia zemli nekampaktna tsiagnulisia $\mathrm{Z}$ paunochnaga zakhadu na paudnevy uskhod ad Baltyiskaga mora da viarkhouia Shchary", in M. Ermalovich, Pa sliadakh in 1991, 33; "na zakanchenne gavorki ab litouska-baltskikh zemliakh znou vernemsia da Starazhytnai Litvy" - ibid., 34.

${ }^{10}$ Ibid., 27, 32, 33 . 
Lithuania $^{11}$. However, Ermalovich fails to make any distinction between the five senior dukes and the rest: he refers to all twenty dukes as 'senior'"

b) When the Sword-Brethren invaded Nalšia or Alšènai (in the sources these names are confused with one another) in the late $1220 \mathrm{~s}^{13}$, they found Lithuanians in those areas ${ }^{14}$.

c) Describing the Battle of Šiauliai (1236), the Livonian Rhymed Chronicle notes that the Teutonic Knights marched into Lithuania and fought with the Lithuanians in the vicinity of Šiauliai ${ }^{15}$.

d) In the mid-thirteenth century the Livonian Rhymed Chronicle refers to the Žemaitians as Lithuanians ${ }^{16}$.

e) According to Ermalovich, the Slav or Slavonicised Mindaugas of Novgorodok conquered the "Baltic-Lithuanian" lands in 1248 at the earlies $t^{17}$. But a document issued by the papal legate William of Modena in 1243 refers to the borders of those ("Lietuvian") territories with Sudavia and Skalvia as Lithuanian borders ${ }^{18}$.

Probably before too long the Žemaitians, Nalšians, Deltuvians and the Lithuanians inhabiting the region of Šiauliai or the lower reaches of the Nemunas, will also be labelled an "obscure tribe". Before this happens, let us see how this has already happened to the Lithuanians described by Henricus Lettus. Ermalovich contends that the ethnonym "Lethones" used here cannot refer to the Lithuanians, since the Latin and German for Lithuanians is "lithuani"/litauer"19. Moreover, the duke of Jersika could hardly have been dealing with Lithuanians (as the context makes clear ${ }^{20}$ ) because, Ermalovich claims, Jersika was inhabited not only by

11 "biakhu zhe imena litov'skikh kniazei: se stareishei [...], a zhemot'skyi [...], a Rush'kovichev [...], a se Bulevichi [...], a se kniazi iz Diavoltvy [...]" (and these were the names of the Lithuanian dukes: the senior (dukes) were [...], the Zemaitijans were [...], the Rushkovichi were [...], the Bulevichi [...], and the dukes of Deltuva were [...]"): Polnoe sobranie nusskikh letopisei [PSRL], II Moscow, 1962, col. 735-736 dukes".

${ }^{12}$ Ermalovich, $\mathrm{Pa}$ sliadakh, 1991, 33: "in it are mentioned more than twenty senior

${ }^{13}$ E.Gudavičius, Kryžiaus karai Pabaltijyje ir Lietuva XIII amžiuje, Vilnius, 1989, 43-44.

${ }^{14}$ Livländische Reimchronik [LR], L. Meyer, Paderborn, 1876; Hildesheim, 1963, 42-43. Scholarship has dated this event credibly back to 1229: $L R$ mentions it before the battle of Saule (1236) and it is clear that by 1230 the Knights were established at Jersika. The settlement at Jersika can be connected with the successful campaign of 1229 - see: E. Gudavicius, op. cit., 43-44.

${ }^{15} L R, 44-45$ : "zu Littowen man do reit / [...] kein Soule sie karten wider / [...] die Littower sie mit not / zuletzt mit boumen felten tot"

${ }^{16}$ LR, 103: "die burc, den die Lettowen, / die Sameiten sin genant, / tet wil we"; 125 : "Die Lettowen al zu hant, / die sameiten sint genant [...]"; 228: "von Sameiten ein her gerant, / die sint auch Lettowen genant".

${ }^{17}$ M. Ermalovich, Pa sliadakh, 1989, 57-67.

18 "De non conversa autem terra [...] sicut claudit mare salsum ab occidente, et flumen Memele ab aquilone, et a meridie flumen Pregore versus orientem usque ad terminos Letuinorum": Preussisches Urkundenbuch [PUB] I,1, Königsberg, 1882, 109.

19 M. Ermalovich, Starazhytnaia, 269.

${ }^{20}$ Henricus Lettus, Chronicon Livoniae in the Russian edition: Genrikh Latviiskii, Khronika Livonii, Moscow-Leningrad, 1938 [CLiv], 313. 
Latgallians but also by Semigallians and Curonians ${ }^{21}$. As far as this nugget of historical geography is concerned, we should recall that the Selonians separate the Semigallians from Jersika and that the Curonians dwelt even further to the west. But this is not the point surely political alliances do not depend on a common border. Where the forms "lithuani" and "litauer" are concerned, Ermalovich should realise that these are mostly late forms. Thirteenth-century German texts, such as the Livonian Rhymed Chronicle, most often refer to Lettowen, Littowen, Letowen ${ }^{22}$. The spoken language must have employed similar forms, thus in Latin sources composed by Germans the forms for Lithuania are usually "Lethovia", "Luthavia" 23 , and those for Lithuanians: "Lettowii", "Let[h]owini"24. Henricus Lettus's "Lethonia" 25 is a variant of "Lethonia" and his "lethones" is even closer to the vernacular form than the other Latin derivative "let[h]owini". In Alexander IV's bull (1255) and the Danish Liber Censuum Daniae ${ }^{26}$ the name for Lithuania is almost exactly the same as that used by Henricus Lettus. The forms "Lit[h]uania" and "Lit[h]uani" and their variants come from Polish sources and texts influenced by Polish and $\mathrm{Czech}^{27}$. Ermalovich fails to appreciate an elementary principle: that in order to evaluate an ethnonym mentioned in one source it must be compared with forms employed in other texts.

Ermalovich's argument is demolished by comparing Henricus Lettus with the Novgorodian First Chronicle, where, sub anno 1221, we find this "obscure Lethonian tribe" 28 in alliance with the Novgorodians, who call their helpmeets "Lithuanians"29.

Following Ermalovich's rules, we should look for an example of Henricus's "Lethonians" in the "Baltic-Lithuanian" lands. Thus in

${ }^{21}$ M. Ermalovich, Starazhytnaia, 269.

${ }^{22}$ See n.n. 14-16 above.These are the "ancestors of the Lithuanians" whether we agree with Ermalovich's ground rules or not. See also $L R, 347-348$.

${ }^{23}$ Liv-, Esth- und Curländisches Urkandenbuch, 1, Reval, 1853) [LUB], 284: "regnum Luthavie..."; 312: "Mindowe, Dei gratia rex Letthowie..."; 312-313: "in regem Lettowie..."; Gedimino laiškai [GI], Vilnius, 1966, 21: "Mindowe, dei gratia rex Lettowiae..."; PUB, I, 2, Königsberg, 1909, 277-278: "episcopus Lettowie..."; 101-102: "Letowiam..."; 196-197: "Letowiam..."; 197-198: "Letowie...".

${ }^{24}$ Cf. n. 18 above; Preussische Regesten bis zum Ausgang des 13. Jahrhunderts, Altpreussische Monatsschrift, XI, 1874, 211: "usque ad finem castrorum exercitus Lettowiorum et Sambitarum..."; Scriptores renum prussicanum [SRP], I, Leipzig, 1861, 125-126: "Trinota filius regis Lethowinorum...".

${ }^{25}$ CLiv, 304.

${ }^{26}$ PUB, I, 2, 1909, 17-18: "alios infideles in Lectonia ac Gzestuesia". Other bulls of Alexander IV show that "Lectonia" is a variant form of "Lectowia". See: ibid., 21-22 ("Lectowia"), 23-24 ("Lectouia"). See also n. 125.

${ }^{27}$ PUB, I, 2, 1909, 1: “Licwan(enses)..."; 2-3: "Litwanos..."; 5: "Litwanos..."; 7-8: "Litwanos..."; 162-163: "Lituani..."; 166-167: "Litwani..."; 197-198: "Lituanorum..."; Pomniki dziejowe Polski [PDP], 2, VIII, Warsaw, 1970. 115: "Lithwanorum..."; 116-17: "Lithwani..."; PDP, 2, V, Warsaw, 1978. 90-91: "Mendoch rex Lytwanorum a Litwanis occiditur [...] Stroynat potens prinseps Lituanorum...".

${ }^{28} \mathrm{CLiv}, 411-12$.

${ }^{29}$ PSRL, III, St.Petersburg, 1841, 38. 
1208 we find that the "Lettonians" were indeed neighbours to the Semigallians - during the night they were in Semigallia and the next day in "Lettonia" 30 . Thus we have a sixth case to add to the evidence cited above illustrating the Lithuanian nature of these "BalticLithuanian" lands. Taking this game a step further, perhaps all these examples prove merely that the inhabitants of these lands were "Lithuanian", because they were already under the hegemony of the Slavonic "Chronicle" or "Ancient" Lithuania. Let our author speak for himself: "research asserts the existence of a relatively uniform state in Lithuanian territory by the early thirteenth century, as is shown by the 1219 Treaty. But this assertion can hardly be credited"31. It remains only for the author to associate the conquest of "BalticLithuanian" lands from Novgorodok not with Mindaugas, but with other(s) from the twelfth, or better still, tenth or eleventh centuries when the Lithuanians were not recorded by the chronicles, or if so, only once or twice. Then it would be possible to produce an even more original concept. However, we should now relate the arguments why the inhabitants of "Baltic-Lithuanian" lands should not be called Lithuanians.

The eastern part of modern Lithuania should be called simply Aukštaitija (Upland). This is based solely on toponymical evidence Aukštaičiai, Aukštynè, Aukštuoniai, Aukštadvaris, Aukšteliai ${ }^{32}$. With the exception of the first example, all these names derive not from "Aukštaitija" but from "aukštas" (high). Thus here we have no ethnonymical component. The author's linguistic expertise is revealed for what it is. This is the second case where ignorance of historical geography leads to a serious error. Even in Old West Russian Aukštadvaris is called Vysokii Dvor (High Manor), thus it is clear that the Aukštaičiai have nothing to do with the name.

The author cites the Teutonic Chronicler Peter of Dusburg who refers to Lithuanians (as the author puts it) when it would be more accurate to say Russians ${ }^{33}$. It is true that in one such passage the Chronicler describes a march on Grodno as an attack on Lithuania and elsewhere he speaks of a Russian (singular) in the Lithuanian army $^{34}$. It is obvious to any one that the Lithuanian state existed and that it included Grodno, which provided soldiers for the Lithuanian army. Following Ermalovich's logic an extract from the south-west Russian Ipat'evskaia Chronicle which refers to a Prussian in the Russian army ${ }^{35}$ would lead to the conclusion that the Russians were, in fact, Prussians.

${ }^{30} \mathrm{CLiv}, 304:$ :"profecti sunt in terram Semigallorum [...] procedentes prope Lethoniam, nocte quiescunt [...]. Procedunt tamen audacter in Lethoniam...".

${ }^{31}$ M. Ermalovich, Po sliadakh, 1991, 33.

${ }^{32}$ Ibid., 28.

${ }^{33}$ Ibid., 29.

${ }^{34}$ SRP I, 1861, 162-172.

${ }^{35}$ PSRL, II, 1962, 886-887. 
The author attempts to show that the Lithuanian attack on Semigallia noted by Henricus Lettus sub anno 1201 did not originate from modern Lithuanian territory. Allegedly it would not have been reasonable for the assailants to use the flow of the River Dvina to reach Semigallia, as the latter was on the left bank of the river and it would have been more convenient to travel overland ${ }^{36}$. The conclusion is drawn that the Lithuanians sailed along the (frozen) river $^{37}$. In fact, the Lithuanian army travelled by sledge along the perfect road provided by the frozen Dvina ${ }^{38}$. At that time Semigallia stretched as far as the Gulf of Riga and the Semigallian winter port had just been blocked $^{39}$. Thus, it made perfect sense to march along this route from north-eastern Lithuania. What is more, Jersika provided support for the Lithuanians and this city's garrison was at Selpils ${ }^{40}$. Thus this direct route along the Dvina to northern Semigallia involved no detour.

Ermalovich seeks to locate the Bulionis dukes in modern Belorussia by indicating such toponyms as Balevichi, Buliovsk Marshes, the river Bulovich ${ }^{41}$. The unsuitability of the first example requires no further commentary. The remaining two hydronyms are well explained by the Polish verb "bulgać" (gurgle). Other west Slavonic toponyms, cited by the author - Bullitz, Bullen ${ }^{42}$, confirm our argument since even if it were Belorussian/Slavonic, the Bulionis clan did not live in that region. The same goes for the Pomeranian place name Ruskewitz which the author adduces as evidence of the nonLithuanian nature of the Ruszkaitis ${ }^{43}$ clan. We might as well look for similar sounding toponyms anywhere - in China, perhaps.

Similar conclusions may be drawn concerning Ermalovich's use of west Belorussian toponyms which he alleges are connected with Lithuanian dukes - indeed they are, as Ochmanski's study of the ethnic Lithuanian eastern boundary ${ }^{44}$ shows: Jutkai (Medilas, Miadzel District) and Daujotai (Braslav District) ${ }^{45}$ belonged to Nalšia. My own investigations have shown how Duke Daujota lived in Nalšia ${ }^{46}$. Juodikis could also have gained estates there, either as a result of his deportation thither by Mindaugas or a donation of Mindaugas. The same can be said of Tautvilai (Pruzhany District) ${ }^{47}$. Following his rec-

${ }^{36}$ M. Ermalovich, Po sliadakh, 1991, 36.

${ }^{37}$ Comp. - CLiv, 268: "qui postea hyeme subsequentes cum exercitu magno Dunam descendentes Semigallian tendunt".

${ }^{38}$ Ibid., 277, 296, 297; LR, 178-180.

${ }^{39} \mathrm{CLiv}, 267$ : "venerandus Romane sedis antistes omnibus Semigalliam mercationis causa frequentantibus districte portum ipsorum sub anathemate prohibet".

${ }^{40}$ Ibid., $299,313$.

${ }^{41}$ M. Ermalovich, Po sliadakh, 1991, 30.

${ }^{42}$ Ibid.

${ }^{43}$ Ibid.

${ }^{44}$ J.Ochmański, Litewska granica etniczna na wschodzie od epoki plemennej do XVI wieka, Poznań, 1981.

${ }^{45}$ Ibid., 27.

${ }^{46}$ E. Gudavičius, Bandymas lokalizuoti XIII a. lietuvių kunigaikščių valdas, $L M A D A, 3$ (88), 1984, 70-71.

${ }^{47}$ M. Ermalovich, Po sliadakh, 1991, 27. 
onciliation with his uncle Mindaugas, Tautvilas could very well have acquired estates not far from Volkovysk. The more so since he (together with Prince Vaišelga) arrested Prince Roman ${ }^{48}$ in 1258/9 during the invasion led by the Tatar warlord, Burunday. Roman was connected with Volkovysk. It is more difficult to account for the places called Rukly (Orsha District) ${ }^{49}$ but there is no reason to deny that these places associated with Mindaugas' son Ruklis were also inside Lithuania.

All these toponyms have been used to support the theory that Bulius, Ruškys and other Lithuanian surnames which in transmission were distorted to Vishimut, Kintibut, Vonibut, Butovit, Vizheik, Vishlii, Kitenii, Plikosova, Sirvid are not Lithuanian but Slavonic ${ }^{50}$. V. Iurgevich considers the names of other Lithuanian princes to be Slavonic: Gediminas, Kęstutis, Mindaugas, Skirgaila, Svitrigaila, Vainys, Vaišelga, Vytautas, Vytenis, Živinbudas ${ }^{51}$. There is no need to explain their Lithuanian origin nor to comment further on Ermalovich's lack of linguistic competence ${ }^{52}$. That is a matter for philologists. I will comment merely on the historical implications of the author's arguments. From the thirteenth century the Ruškaitis clan led raids on Volyn; their lands should therefore, it seems, be located in the Pinsk region ${ }^{53}$. Following such logic, the Žemaitians should have lived around Galich, since in 1228 they raided the outskirts of Kielcy and Sandomierz in Poland ${ }^{54}$. One of the names Ermalovich lists as Lithuanian is, in fact, Russian: $\mathrm{Khval}^{55}$. Why should not a Russian have fled for asylum to Lithuania, just as Lithuanians fled to Russia on occasion (i.e. Tautvilas, Gedvydas, Daumantas)? The Ipat'evskaia Chronicle notes one such example: Evstafy of Riazan'56. But Khval was not a Ruškaitis, as Ermalovich mistakenly construes - only Sirvidas was the Ruškaitis mentioned in this text ${ }^{57}$. Thus we also reject the idea that Lithuanian dukes were Slavonic. Moreover the author should know that in Mindaugas' day Dunaburg ${ }^{58}$ did not exist - it was built by the Livonian Knights in the $1270 \mathrm{~s}^{59}$.

Ermalovich attempts to derive the Lithuanian toponym "Alsen" mentioned in the Livonian Rhymed Chronicle which could refer to Alšènai or Lake Alšis, from modern German (der Aal and der See) to fit the "Eel" lakes of Western Belorussia. This would not be so bad if this were linked with the Chronicle's German, that is, if the

${ }^{48}$ PSRL, II, 1962, 847.

${ }^{49}$ M. Ermalovich, Po sliadakh, 1991, 27.

${ }^{50}$ Ibid., 30.

${ }^{51}$ Ibid., 46.

${ }^{52}$ See $n .32$ above.

${ }^{53}$ M. Ermalovich, Po sliadakh, 1991, 31.

${ }^{54}$ PDP, 2, VIII, 1970, 83.

${ }^{55}$ M. Ermalovich, Po sliadakh, 1991, 30.

${ }^{56}$ PSRL, II, 1962, 855.

${ }^{57}$ Ibid., 840.

${ }^{58}$ M. Ermalovich, Po sliadakh, 1991, 31.

${ }^{59} \mathrm{LR}, 187$. 
word were a common noun from Standard German, but as it stands, Ermalovich cites this word as a Germanic hydronym ${ }^{60}$. Such etymologising is used to prove that Nalšia was the most Slavonicised areas of Lithuania in that period ${ }^{61}$. Daumantas, duke of Nalšia was also a Slav - because he fled to Pskov ${ }^{62}$. We ought then to conclude that the other Nalšian duke, Šiukšta was a German because he fled to Livonia $^{63}$.

Ermalovich amends the orthography of Deltuva in the Ipat'evskaia chronicle to Latvia (Lotva) in order to prove that Latvians dwelt in Lithuania ${ }^{64}$. This logic implies that Spain derives from Spannheim. The author supports his derivation by citing the variant reading in Khlebnikov's transcript ot Ipat'evskaia where the sound Deltuva resembles Latvia ${ }^{65}$. It is obvious that this error is due to the transcriber of the Chronicle protograph who had no knowledge either of the Lithuanian language or ancient Lithuanian realia. Ermalovich miscites the page number of this text, giving p.863 instead of p. $736^{66}$. Deltuva is mentioned on both pages ${ }^{67}$, but the point is worth making, because, if textual variants are to be taken into consideration, the form of the Khlebnikov variant on p.863 actually sounds Lithuanian rather than Latvian ${ }^{68}$.

The author attempts to prove that the western border of Aukštaitija followed the Šventoji river. He bases his argument on "a German chronicle", but should say "the Livonian History". It would follow that when attacking Žemaitija the Teutonic Knights came upon Ukmergè and the Šventoji ${ }^{69}$. Naturally, one may base one's arguments on secondary sources but when primary sources are available they should be taken into account. Thus Hermann v. Wartberge points out that the Livonians who raided Žemaitija in 1332 reached as far as Mažeikiai and Vindeikiai ${ }^{70}$. Nineteenth-century editors commenting on this text located Vindeikiai by the river Širvinta ${ }^{71}$, but there is also a Vindeikiai in Žemaitija (Skuodas District, Notènai) ${ }^{72}$. In 1333 three campaigns were led: the first to Žemaitija; the second to Ukmerge; the third to Polotsk ${ }^{73}$. If we were to consider all three as parts of a single campaign then it would follow that the whole of Lithuania was traversed in one go as far as Polotsk and that the soldiers brought their

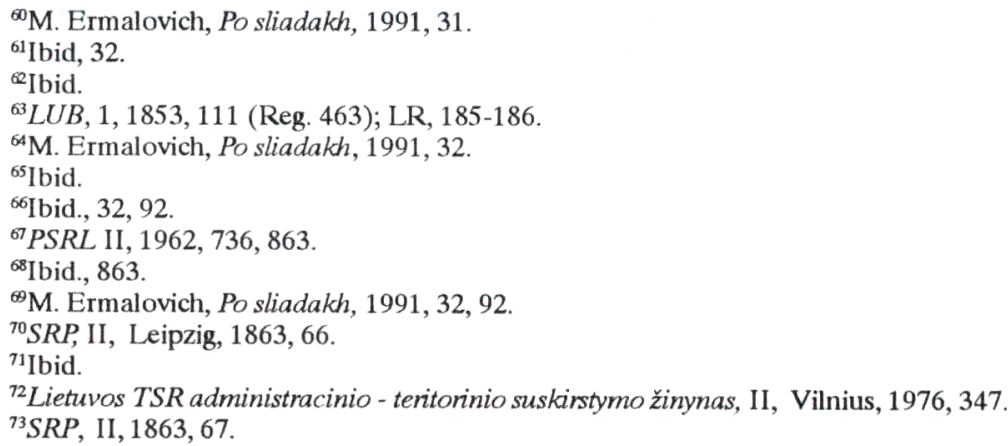


boats with them as far as the Dvina (quite a feat for fourteenth-century tracks and drays). The second campaign can be easily distinguished from the first by its introductory phrasing: "in 1333 the same Master was ..."74. Ermalovich drew his conclusions without consulting the sources. This misdemeanour is not the point. Even if the text supported the hypothesis that the raid on Žemaitija reached as far east as Ukmergé, one should appreciate that chroniclers can be inaccurate in their expressions. Thus the same Wartberge notes in 1372 that the grand master campaigned in the land of Medininkai (Žemaitija) and crossed the territory as far as the Neris ${ }^{75}$; in 1375 the master of the Livonian Order attacked Upytè and after ravaging all in his path for nine days reached Ukmerge $\dot{e}^{76}$. Following Ermalovician logic, we should conclude that Medininkai stretched as far as the Neris, and Upytè as far as Ukmergè. That Aukštaitija extended as far as the Nevéžis is best illustrated by Peter of Dusburg's entry for 1294/1300 where the Romainiai area (outside modern Kaunas) is located in Aukštaitija ${ }^{77}$.

Ermalovich had to transfer the borders of the fourteenth-century Aukštaitija as far as the Šventoji in order to provide a historical justification for using nineteenth-century Slavonic jargon which called all Lithuanians "Žemaitians"78.

Such are the arguments which support the claim that in the thirteenth century the "Baltic-Lithuanian" lands were not called Lithuania and their inhabitants were not "Lithuanians".

2.

Ermalovich's "Chronicle" or "Ancient" Lithuania is represented on a special map which defines its frontiers in the following way: it is a small area west of Novgorodok, on the upper reaches of the Nemunas on both banks of the river. In the north it is bordered by the Berzuna and in the south by the Upper Shchara, near Minsk ${ }^{79}$. The arguments supporting this localisation are as follows:

1. Sub annis 1159-62 the Ipat'evskaia Chronicle mentions Duke Volodar whose allies were Lithuanians dwelling near Minsk ${ }^{80}$. We have already seen how Ermalovich mistakenly equates vicinity with alliance $^{81}$.

2. The Ipat'evskaia Chronicle records how Vaišelga founded a monastery by the Nemunas "between Lithuania and Novgorodok" 82 . As most scholars do, Ermalovich associates this monastery with the

\footnotetext{
${ }^{74} \mathrm{Ibid}$.

${ }^{75} S R P$, II, $1863,101$.

${ }^{76}$ Ibid., 115-116.

${ }^{77} S R P, \mathrm{I}, 1861,159$

${ }^{78}$ M. Ermalovich, Po sliadakh, 1991, 33.

${ }^{79}$ Ibid., 23-24, 43.

${ }^{80}$ Ibid., 21.

${ }^{81}$ Cf. n. 21 above.

${ }^{2}$ PSRL, II, 1962, 859.
} 
convent at Lavrashev ${ }^{83}$ and this is very likely. However, can it be proven that the Lithuania noted here stretched only as far as the Berzuna? The weakness of this argument is sensed by Ermalovich himself, who builds another unproven hypothesis upon it: Lavrashev is to the north-east of Novgorodok, but there there was that "Ancient Lithuania" which cannot be equated with "Baltic-Lithuania" and Aukštaitija ${ }^{84}$. Why this should be has already been argued by the author, and he adds no further evidence here in substantiation. Here we might recall the work of Ochmanski which explains that the Lithuanian ethnic boundaries were in the immediate vicinity of Minsk $^{85}$. So Lithuania was to the north-east of Lavrashev. Besides, on his map of "Ancient" Lithuania Ermalovich uses "Lithuanian" place names ${ }^{86}$ which are, in fact, the best evidence available for the later slavonicisation of those areas.

3. In 1190 Prince Riurik of Kiev prepared to march in support of the princes of Pinsk against Lithuania ${ }^{87}$. Thus, Ermalovich concludes that "Lithuania was near the principality of Pinsk, beyond its marshlands" 88 . One could not agree more, but a question remains: how does this prove that Lithuania did not stretch to the north of the Berzuna too?

4. In 1246 and 1247 (the dates given in the Ipat'evskaia chronicle have not been amended here) Lithuanians ravaged Volyn and Melnik ${ }^{89}$ via Pinsk. This is taken to imply that they were coming from "Ancient" Lithuania ${ }^{90}$. Why could they not have come from more distant Lithuanian lands? To help us clarify what this means, let us take another example from this chronicle. In late 1248 the Žemaitijan duke Vykintas and three of Mindaugas' nephews campaigned as far as Smolensk ${ }^{91}$. According to Ermalovich's logic, Vykintas must have been a Nalšian living close to Polotsk ${ }^{92}$. He was not. We might note en passant that Ermalovich misunderstood this text too $^{93}$ : Lekovnia is not a place-name but a distortion of the personal name, Lengvenis (as is clear from subsequent references) ${ }^{94}$.

5. Having attacked Volyn in 1262, the Lithuanians retreated towards Pinsk ${ }^{95}$ in the direction of Jaselda and Nebel ${ }^{96}$. How could they reach Lithuania without crossing this region?

\footnotetext{
${ }^{83}$ M. Ermalovich, Po sliadakh, 1991, 21.

${ }^{84}$ Ibid.

${ }^{85}$ See n. 45 above.

${ }^{86}$ M. Ermalovich, Po sliadakh, 1991, 23, 43.

${ }^{87}$ PSRL, II, 1962, 672.

${ }^{88}$ M. Ermalovich, Po sliadakh, 1991, 21.

${ }^{89}$ PSRL, II, 1962, 797-798.

${ }^{90}$ M. Ermalovich, Po sliadakh, 1991, 21.

${ }^{91}$ PSRL, II, 1962, 815.

${ }^{92}$ Cf. nn. 53-54 above.

${ }^{93}$ M. Ermalovich, Po sliadakh, 1991, 21.

${ }^{94}$ PSRL, II, 1962, 798.

${ }^{95}$ M. Ermalovich, Po sliadakh, 1991, 21-22.

${ }^{96}$ Ibid., 855-856.
} 
6. In 1253, the Ipat'evskaia Chronicle relates, the Lithuanians sent out scouts to reconnoitre Lake Zietela. The Galicians pursued these scouts as far as the Shchara and next day devastated the whole of the Novgorodok duchy ${ }^{97}$. Ermalovich argues that these scouts had been guarding the borders of "Ancient" Lithuania and that the Galicians invaded and subdued "Ancient" Lithuania which stretched to the south-east of Novgorodok before breaking into the duchy of Novgorodok ${ }^{98}$. However, the word "Lithuania" here refers not to a country but to people and it follows from the text that the Galicians only had to repel the guards in order to enter the Novgorodokian territory.

7. Sub anno 1255 the Ipat'evskaia Chronicle records that the Galicians "marched to Lithuania, to Novgorodok" to fight". Here Ermalovich envisages the same situation (which he uses to support his claim, of course) as in 1253: to reach Novgorodok the Galicians traversed "Ancient" Lithuania ${ }^{100}$. But why should they have not been going to Lithuanian Novgorodok in the Lithuanian state? Is it not the same as when the Chronicle records Lithuanians going "to Russia, towards Smolensk"101. Many more such examples could be given ${ }^{102}$.

8. Mindaugas' Lithuania must needs have been adjacent to Novgorodok $^{103}$, since in 1235 Daniil of Galich-Volyn requested assistance from Mindaugas of Lithuania and Izaslav of Novgorodok in his campaign against Poland ${ }^{104}$. It would follow that Kursk, Pinsk and Novgorod were located in the same vicinity because the armies of these cities joined together in $1228^{105}$.

9. Without a doubt it is of paramount importance for scholars to explain what is meant by Mindaugas' Lithuania and his castle of Voruta $^{106}$. However, I would emphasise that we must differentiate between the localisation of Voruta and the arguments which are provided in support of such a localisation. It is possible to agree with the one and not the other. Here I will not go into the discussion of whether Voruta was in fact in the upper reaches of the Nemunas, but limit myself to analysing Ermalovich's argument that it was so placed. He links Voruta with the River Ruta in what he defines as "Ancient" Lithuania ${ }^{107}$. He concludes that Mindaugas' castle was called Ruta (other scholars advance this argument too) and that the first syllable "Vo" is the preposition ("to") ${ }^{108}$. All those who proffer this explana-

${ }^{97}$ PSRL, II, 1962, 818-819.

${ }^{98}$ M. Ermalovich, Po sliadakh, 1991, 22.

${ }^{99}$ PSRL, II, 1962, 828-829.

${ }^{100}$ M. Ermalovich, Po sliadakh, 1991, 22.

${ }^{101}$ See n. 91 above.

${ }^{102}$ PSRL, II, 1962, 787, 896.

${ }^{103}$ M. Ermalovich, Po sliadakh, 1991, 24.

${ }^{104}$ PSRL, II, 1962, 776.

${ }^{105}$ Ibid., 753.

${ }^{106}$ M. Ermalovich, Po sliadakh, 1991, 24.

${ }^{107}$ Ibid., 24-25.

${ }^{108}$ Ibid., 25. 
tion seem to miss one essential point: such a reading ignores the grammatical construction of the phrase: Ruta is in the nominative case but vo" governs the accusative ${ }^{109}$. Thus reading Voruta as Ruta is a complete misunderstanding arising from an inability to decline a Russian noun following a preposition.

10. Countering the opinion of R. Batūra, Ermalovich asserts that the Lithuanian historian refers to the "land of Lithuania" which Burundai invaded in 1258 as Novgorodok (which belonged to Lithuania) ${ }^{110}$. Batūra merely contends that Burundai marched from the south east towards Novgorodok (that is, the Tatar leader entered Lithuanian territory via Novgorodok ${ }^{111}$. Ermalovich criticises a Lithuanian text without being familiar either with the language or even the alphabet (which has not contained a " $w$ " for a long time) ${ }^{112}$.

11. And thus this "Ancient" Lithuania became Slavonic: "encompassed by Slavs it became not so much "Baltic" as "pagan"113. How this came to pass, the author does not explain. He probably regards it sufficient to refer to the Khlebnikov manuscript of the Ipat'evskaia Chronicle which lists the Lithuanians among Slavonic tribes ${ }^{114}$, but this list of tribes is merely a gloss added by a later copyist ${ }^{115}$ who did not understand who the defunct and obscure Lutichi were - the name certainly sounds like "Lithuanian" 116 . It is worth noting that this distinction is absent from the Pogodin manuscript ${ }^{117}$ which was copied from the Khlebnikov text ${ }^{118}$.

The slavonicisation of the Lithuanians is a leitmotif running through many passages of Ermalovich's book. What such an argument is worth is illustrated by citing an entry (s.a. 1213) from the Pskov Chronicle which refers to Prince Vladimir of Pskov as a Lithuanian ${ }^{119}$. The author does not appreciate the fact that independent chronicle compilation began in Pskov only in 1237 and that before this date material was copied from the Novgorodian record ${ }^{120}$. Thus the Novgorodian First Chronicle records how in 1213 the Lithuanians attacked Pskov after the citizens had expelled their prince (and there is no reference here to his being a Lithuanian) ${ }^{121}$. In retelling this incident the Pskovite chronicler regards the raid as Lithuanian revenge for Vladimir's expulsion rather than opportunistic marauding.

${ }^{109}$ PSRL, II, 1962, 818.

${ }^{110} \mathrm{M}$. Ermalovich, Po sliadakh 1991, 25; see also notes in pages 90-112.

${ }^{111}$ R. Batūra, Lietuva tautu kovoje prieš Aukso ordq, Vilnius, 1975, 132.

${ }^{112}$ M. Ermalovich, Po sliadakh, 1991, 91 (nn. 129, 131, 133).

${ }^{113}$ Ibid., 26.

${ }^{114}$ Ibid.

${ }^{115}$ PSRL, II, 1962, 5.

${ }^{116}$ Ibid.

${ }^{117}$ Ibid.

${ }^{118}$ Ibid., p. XII.

${ }^{119}$ M. Ermalovich, Po sliadakh, 1991, 38-39.

${ }^{120}$ Istochnikovedenie istorii SSSR, Moscow, 1973, 64.

${ }^{121}$ PSRL III, 1841, 32; Cf. V.T.Pashuto, Obrazovanie Litovskogo gosudarstva, Moscow, 1959,48 
Such is Ermalovich's portrayal of slavonicised "Ancient" Lithuania. It is obvious that the author is unfamiliar with the Lithuanian Army muster lists preserved in the Lithuanian Metrica, and the demographic studies of H. Lowmianski and W. Conze. These would have led him to understand that this tiny area would have been unable to provide enough soldiers to meet even the number of battle casualties which he cites as evidence of thirteenth-century Lithuanian weakness and Belorussian strength ${ }^{122}$. We can cite several references to Lithuania in the first half of the thirteenth century which cannot possibly fit the parameters adduced by Ermalovich:

describing the first years of the thirteenth century, the Livonian Rhymed Chronicle lists the Baltic tribes, referring to Lithuanians as the most powerful of these ${ }^{123}$.

the Chronicle of Alberic of Trois-Fontaines (1228) notes the Lithuanians among converted tribes ${ }^{124}$.

the Liber censuum Daniae (compiled in the second quarter of the thirteenth century on the basis of earlier records) includes Lithuania in its general survey of Baltic lands and peoples ${ }^{125}$.

Ermalovich might consider expanding "Ancient" Lithuanian borders further to the east, say to Oboltsy territory. There would certainly be more Slavs there and the sources deal very scantily with this region: what perfect ground for changing arguments.

3.

The arguments for the slavonicisation of Lithuania and Slavonic colonisation are based on the following considerations:

1. One aim is to deny the pressure of Lithuanian main force on Russian lands by concentrating on Lithuanian defeats and growing losses ${ }^{126}$. V.T. Pashuto also examined these losses and arrived at a completely different conclusion, namely that the growth in losses reflects the intensification of Lithuanian attacks on Rus' ${ }^{127}$. This logical deduction may be supplemented by a question: how many Russian attacks on Lithuania are recorded for this period? The most picturesque confirmation of Lithuanian might must be the famous tirade against the "Lithuanian wolf" in Henricus Lettus" ${ }^{128}$.

2. Combined campaigns involving Lithuanian and Polotian forces are adduced to prove that the Lithuanian offencives were in fact part of Polotian policy and that the Lithuanians were merely tools in the hands of the dukes of Polotsk ${ }^{129}$. In 1180 the Lithuanians did lead the

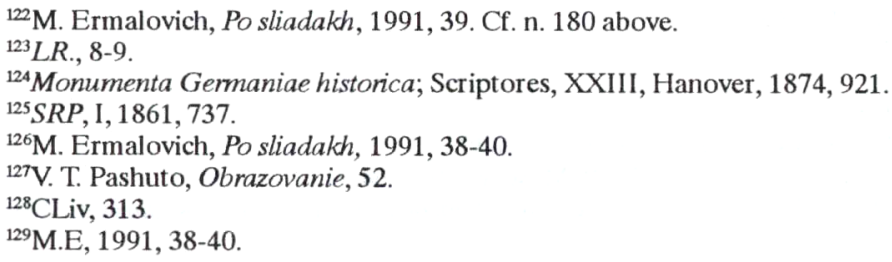


Polotians ${ }^{130}$, but why is it that in $1200,1210,1225,1229,1234$ only the "leaders" are recorded ${ }^{131}$. Moreover s.a. 1234 they are accurately described $^{132}$. The duke of Polotsk had concluded an alliance with the bishop of Riga ${ }^{133}$ against these "leaders" in 1222 - of course, it would be naive to discern an unambiguous, constant policy motive here! Furthermore the "power" of Polotsk was well assessed by the Novgorodians who referred to the rulers of Polotsk as "petty dukes"134.

3. On the basis of "Polotsk politics", it is argued that Lithuanian attacks on north-western Rus' took place somewhere on the VitebskSmolensk border ${ }^{135}$. Henricus Lettus clearly indicates whence and whither the Lithuanians marched in 1221: the Novgorodians waited for their Lithuanian allies in Letgallia and then marched on Wenden. The Lithuanians (who numbered only 600) did not separate from the Novgorodians but marched on with them to Pskov before setting off home a month later along the Dvina in Livonia ${ }^{136}$. Thus Polotsk did not feature in this campaign in the least.

4. To back up the "Polotsk policy", it is claimed that when the Lithuanians attacked Novgorod, Polotsk and Smolensk in 1225, Polotsk was not attacked in fact, because the city was not mentioned in the Moscow Theological Academy's copy of the Laurentian Chronicle or the Novgorodian First Chronicle ${ }^{137}$. The Moscow Theological Academy's copy (1206) differs from other chronicles of the Laurentian group and is closest to the Radziwiłł Copy which ends with entries for $1206^{138}$. Thus we are faced with information from different sources. How does this permit us to draw conclusions ex silentio, especially when the campaign is mentioned in other sources? Just because the Novgorodian First Chronicle makes no mention of the Lithuanian raid on Smolensk in 1248/9139, must we doubt the information provided by the Laurention, Rogozha, Ipat'evskaia and Tver Collection chronicles ${ }^{140}$ ? As elsewhere in this book ${ }^{141}$, Ermalovich refers here to textual variants without appreciating the nature of the text(s).

5. Another alleged proof of Polotian policy is adduced from the fact that, as soon as Polotsk and Novgorod had concluded a truce in 1262, the Lithuanians not only ceased their attacks on Novgorod, but also joined the Polotians in providing aid to Novgorod, as in the attack

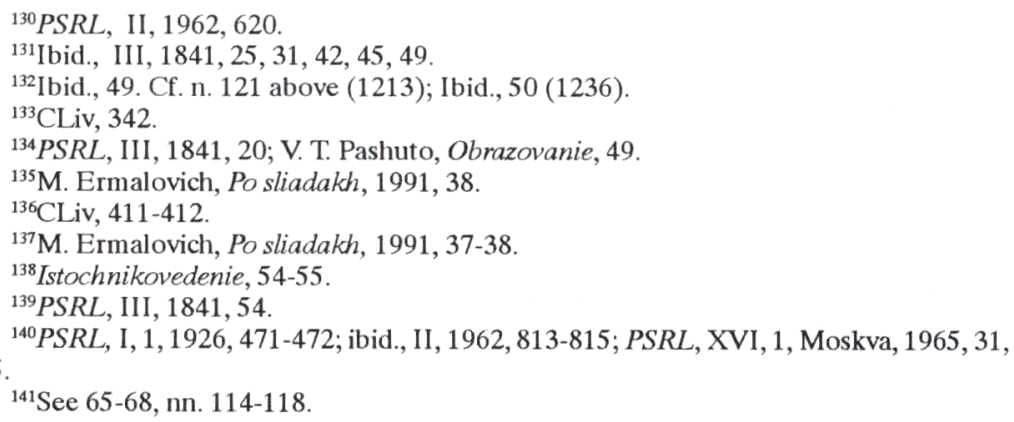


on the Livonian Order in Dorpat in $1262^{142}$. In fact the Lithuanians had concluded a ceasefire with Novgorod themselves, as both the Novgorodian First Chronicle ${ }^{143}$ and the Livonian Rhymed Chronicle ${ }^{144}$ make clear without any reference to Polotsk.

6. The dukes of Pinsk permitted the Lithuanians to cross their territory to get to Volyn. Ermalovich interprets this as proof that Pinsk was using the Lithuanians for its own ends ${ }^{145}$. Following this logic then, the Polish-Lithuanian Commonwealth used Russia against Prussia during the Seven Years' War (1756-63), in 1812 Prussia and the Duchy of Warsaw used Napoleon against Russia, as the Bulgarians did Germany against Greece in 1941.

7. A surprising deduction from obsolete secondary sources is the assertion that Gerdenis was the father of grand dukes Vytenis (c.12951315) and Gediminas (c.1315-c.1342) ${ }^{146}$. It has long been known from data provided by Peter of Dusburg ${ }^{147}$ that the father of these rulers was Pukuveras (Butvydas).

8. References are made to events which the Voskresenskaia Chronicle ${ }^{148}$ attributes to the twelfth century, the incredibility of which is not appreciated in the least ${ }^{149}$. If one actual event is recorded in a given source, the entire text is regarded as equally reliable ${ }^{150}$.

9. The colonisation of the Vilnius region by the Krivichi is deduced from Peter of Dusburg's mentioning this Slavonic tribe ${ }^{151}$. However, Peter placed Krivichi territory in the vicinity of Novgorodok ${ }^{152}$; elsewhere Ermalovich himself notes the connections between Novgorodok and Polotsk ${ }^{153}$.

10. The Slavonic nature of Vilnius is deduced from the work of the Holubowiczes ${ }^{154}$ who are well known for their bias.

11. The declaration that the slavonicised Lithuanians were pagan is based on the assumption that the Lithuanian dukes Mindaugas, Vaišelga, Daumantas and Tautvilas were of Slavonic descent and converted to Orthodoxy ${ }^{155}$. However, it is the Ipat'evskaia Chronicle ${ }^{156}$ which depicts the Catholic rather than Orthodox baptism of

${ }^{142}$ M. Ermalovich, Po sliadakh, 1991, 40.

${ }^{143}$ PSRL, III, 1841, 57.

${ }^{144} L R, 148$.

${ }^{145}$ M. Ermalovich, Po sliadakh, 1991, 40.

${ }^{146}$ Ibid., 45.

${ }^{147} S R P$, I, 1861, 155.

${ }^{148}$ M. Ermalovich, Po sliadakh, 1991, 45.

${ }^{149}$ M.Jučas, Lietuvos metraščiai, Vilnius, 1968, 175-177, 183-184; V. T. Pashuto, Obrazovanie..., 73-76.

${ }^{150}$ M. Ermalovich, Po sliadakh, 1991, 46.

${ }^{151}$ Ibid., 45.

${ }^{152} S R P$, I, 1861, 180.

${ }^{153}$ M. Ermalovich, Po sliadakh,1991, 18.

${ }^{154}$ Ibid., 46, 48, 93.

${ }^{155}$ Ibid., 46.

${ }^{156}$ PSRL, II, 1962, 816-817. 
Mindaugas and Tautvilas. Vaišelga ${ }^{157}$ and Daumantas ${ }^{158}$ accepted Othodoxy only after they had become princes of Rusian Novgorodok and Pskov.

12. Vilnius is regarded as a Slavonic toponym because the Lithuanian Chronicles call the city's river Vilia rather than the Neris ${ }^{159}$. One should not be surprised that chronicles composed in west-Russian use a west-Russian hydronym. As for "Neris", this Lithuanian hydronym is recorded by thirteenth- and fourteenth-century German sources which deal with this river and its source ${ }^{160}$. The assumption that the extent of Belorussian political hegemony is reflected by the spread of the west Russian ("Belorussian") dialect ${ }^{161}$ (hardly the case in the thirteenth and fourteenth centuries) is false. The fact that a Romance language successfully ousted Germanic dialects from the Frankish Empire does not show who actually governed that state (the Frankish analogy has been made by Russian historians for many years).

13. I agree with Ermalovich that the legendary parts of the second and third compilations of the sixteenth century Lithuanian chronicles (annals), including their account of the Lithuanian wars with the Tatars, are the purest fantasy ${ }^{162}$ (why this is so is open to various arguments, but this is not my task here). Ermalovich draws the conclusion that Belorussians were not seeking Lithuanian protection from the Tatars $^{163}$. I am not prepared to deny or accept this conclusion here. There is almost no information about Belorusso-Tatar relations in the thirteenth century and the Lithuanians, as we know, resisted Tatar attacks. We need not decide here why Lithuania conquered Belorussian territories, but it is clear that it did. As for why the Lithuanians were incapable of defending these lands from the Teutonic Knights, let us ask one question: why was it the Lithuanians and not the Teutonic Knights who governed these areas?. I am at a loss as to how to suggest the author might answer this question - perhaps he should label the stroked pottery culture Slavonic.

\section{4.}

How did slavonicised "Ancient" Lithuania come to give its name to the "Baltic Lithuanian" lands?

1. The state name "Lithuania" meant "Belorussia". The second component of the name "Grand Duchy of Lithuania, Rus' and Žemaitija" is attributed to the "Ukraine" and thus there remains "Žemaitija" to refer to what is now called "Lithuania"164. The author

${ }^{157}$ Ibid., 858-859.

${ }^{158}$ PSRL, III, 1841, 58; V. T. Pashuto, Obrazovanie..., 53.

${ }^{159}$ M. Ermalovich, Po sliadakh, 1991, 48, 93.

${ }^{100}$ Senas Latvijas vèstures avoti, 2, 1, Riga, 1937, 197; SRP, II, 1863, 640-641.

${ }^{161}$ M. Ermalovich, Po sliadakh, 1991, 48-49.

${ }^{162}$ Ibid., 50-53.

${ }^{163}$ Ibid., $53-54$

${ }^{164}$ Ibid., 57 
draws on the name of the polity as given by the Lithuanian Chronicles in order to support this theory. In the Krasinski, Raczynski, Rumiantsev and Evreiinov texts of the second edition of the Chronicle we find only the "Grand Duchy of Lithuania and Žemaitija". All four copies were compiled after the Union of Lublin (1569) when Ukraine was part of the Kingdom of Poland ${ }^{165}$. Ermalovich fails to distinguish between the date of the manuscripts and the date of the text; a late copy can record a far older text. This is exactly the case here - the name "Grand Duchy of Lithuania and Žemaitija" existed before the Union of Lublin, as is evident from the Olszewski manuscript (1550) which records this very name ${ }^{166}$. Moreover, the author is unfamiliar with the work of J. Adamus and O. Halecki which deal with the titles of the Grand Duchy and its constituent parts. Various names were current before Lithuania annexed Ukrainian territory. In 1322 and 1323 Gediminas styled himself "king of the Lithuanians and Russians" or "king of the Lithuanians and many Russians"167.

2. Daumantas fled to Pskov and Siuksta to Livonia. There were many more such Lithuanian refugees from Lithuania. Ermalovich maintains that the escape of such people does not prove that the lands to which they fled were occupied by Lithuanians ${ }^{168}$. This statement with which none will quarrel is used to contend that Mindaugas was "probably a deserter to Novgorodok" (from "Ancient" Lithuania) ${ }^{169}$. This "probably" creates an "alternative" which is not based in the sources and this "alternative" is then used as a proved and uncontentious fact. Other considerations of similar validity are adduced to support this "fact".

3. Mindaugas is portrayed as having been a mercenary in the Lithuanian Treaty with Volyn in 1219: Lithuanians had pledged the dukes of Volyn to fight against Poland ${ }^{170}$. The basis of this contention is the verb "privede" 171 which literally means "brought". Bringing can be achieved through order, instigation, request. That instigation or request is meant here follows from the description of the Treaty: the Lithuanians, commanded by the Lord (i.e "thank God") granted peace to Duke Roman's widow and her young sons"172. Volyn had scores to settle with Poland ${ }^{173}$ and opened its territory up to the Lithuanians that these might plunder in Poland. Thus service was rendered for service and the deal was requested by Volyn, not by Lithuania.

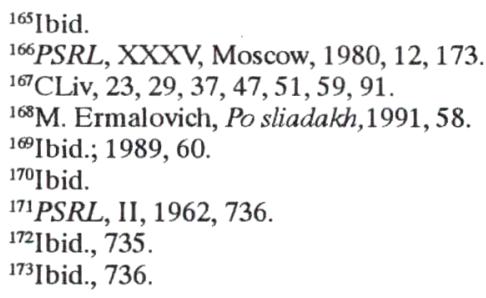


4. In 1237 Daniil Romanovich directed Mindaugas against the Mazovians ${ }^{174}$. The verb used here, "vozvede" 175 has as many meanings as "privede" and no clearer conclusion can be drawn about the nature of this event.

5. A similar case arises with the discussion of Mindaugas' aid to Daniil in $1245^{176}$. As with the 1219 text, the meaning of this entry in the chronicle is also violated: Daniil did not demand Mindaugas' help, he requested it $^{177}$.

6. To Ermalovich's mind, however, the supplicant is superior to his benefactor, since during the siege of Amboten he refers to the Couronians as supplicants but deduces that Mindaugas was a serving boy at their beck and call ${ }^{178}$. The Livonian Rhymed Chronicle sees things differently. According to this source the Curonians did not invite Mindaugas at all but fought with the Germans against the Lithuanians ${ }^{179}$. While we still have the Amboten battle in mind, we might ask how Mindaugas could have brought such a huge army of 30,000 (according to the Rhymed Chronicle) from so small an area as "Ancient" Lithuania ${ }^{180}$ ?

7. Mindaugas had to flee to Novgorodok because following the Battle of Amboten the Teutonic Knights ravaged his lands, weakened his standing and thus encouraged his enemies in Lithuania ${ }^{181}$ to act against him. This statement which loses sight of the geographical perspective is intended to elucidate lines 2,450-2,542 of the Rhymed Chronicle $^{182}$. However, this passage deals with Mindaugas' march on Amboten, not the aftermath of the battle ${ }^{183}$. If Ermalovich has made a mistake in citing line numbers here and has in mind instead the variable conflicts between Mindaugas' nephew Lengvenis and his enemies (Milgrynas, Gineika and Tučius) ${ }^{184}$, which took place after Amboten, then he should know that the final outcome of these squabbles was that Lengvenis' enemies remained in Livonia ${ }^{185}$ (i.e. they were expelled from Lithuania) and Lengvenis avenged himself at Wenden where he killed the Commander of this Livonian castle ${ }^{186}$. Such developments show that far from being weakened, Mindaugas' position was consolidated.

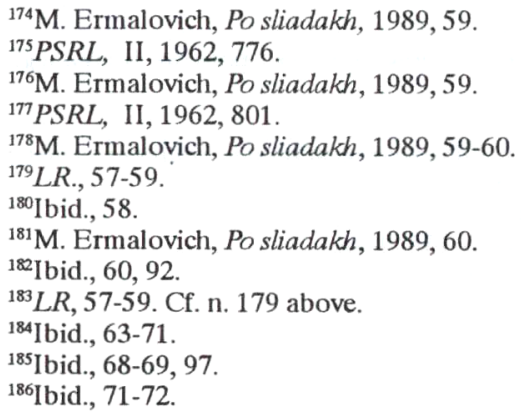


8. Despite all this, "Mindaugas was defeated and had to escape to Novgorodok"187. In support of this assertion Ermalovich supplies his own interpretation of the expulsion of Mindaugas' nephews Tautvilas and Gedvydas. The Ipat'evskaia Chronicle indicates that Mindaugas quarelled with them over Lithuania and occupied the whole of the Lithuanian land ${ }^{188}$. These very words mean to Ermalovich, that until this time Mindaugas possessed no part of Lithuanian land ${ }^{189}$. I will not explain what land this was, for Łowmiański did this long ago ${ }^{190}$. Suffice it to say, that Mindaugas took away all their estates and sent them to fight with his army ${ }^{191}$. How could he issue such commands if he was neither ruler nor even resident in Lithuania, but a refugee in Novgorodok? We might also note that the Rhymed Chronicle refers to Mindaugas as the highest king and lord of Lithuania ${ }^{192}$ when it describes his conflicts with Lengvenis and his foes.

9. Arguments based on the Orthodox baptism of Mindaugas ${ }^{193}$ in the Gustinskaia Chronicle (compiled c.1620) are undermined by accurate information in the Livonian Rhymed Chronicle, the bulls of Innocent IV and the Ipat'evskaia Chronicle which shows that Mindaugas was baptised a Catholic ${ }^{194}$.

10. There is no need to discuss the conclusions about Mindaugas' reign which are supported or otherwise by such "arguments" as we have drawn attention to above ${ }^{195}$. I would note that Andrew was not Bishop of Riga ${ }^{196}$ (that was Nicholas) but master of the Livonian Order. The only instance, which admits some kind of alternative interpretation (albeit not confirmed by any other source), is the note in Ipat'evskaia Chronicle ${ }^{197}$ to the effect that Tautvilas asked Daniil to march on Novgorodok ${ }^{198}$. It would ensue from this that Novgorodok really was an important place in the Lithuanian state. Does anything else ensue? At the beginning of Daniil's action as described in this entry, the entire land of Novgorodok, including eventually its (i.e. Mindaugas') castle was overrun and the "whole of their patrimony was ravaged"199. It is clear from this that Mindaugas' patrimony and his main residence were elsewhere and that during Daniil's attack he was in one way or another ruling both areas.

${ }^{187}$ M. Ermalovich, Po sliadakh,1989, 60.

${ }^{188}$ PSRL, II, 1962, 815.

${ }^{189}$ M. Ermalovich, Po sliadakh,1989, 62.

${ }^{190}$ H.Łowmiański, Studja nad początkami społeczeństwa i państwa litewskiego, II, Wilno, 1932, 106-112.

${ }^{191}$ PSRL, II, 1962, 815.

${ }^{192}$ LR, 63; Vetera monumenta Poloniae et Lithuaniae gentiumque finitimarum historiam illustrantia [VMPL], I, Roma, 1860, 49-51. See n. 156 above.

${ }^{193}$ M. Ermalovich, Po sliadakh, 1989, 61.

${ }^{194} L R, 81-82$; VMPL, I, 1860, 49-51. See n. 156 above.

${ }^{195}$ M. Ermalovich, Po sliadakh, 1989, 63-79.

${ }^{196}$ Ibid., 65.

${ }^{197}$ PSRL, II, 1962, 818.

${ }^{198}$ Ibid., 66.

${ }^{199}$ Ibid., 819. 
This is the way Ermalovich "proves" that Mindaugas fought Lithuania from Novgorodok.

5.

The primary aim of the sections dealing with Vaišelga is to prove that Vaišelga's accession signifies the occupation of Lithuania for after Daumantas had murdered Mindaugas, Vaišelga fled to Pinsk. The sole foundation for this is the Ipat'evskaia entry which relates how Vaišelga marched with the people of Pinsk to Novgorodok, collected the soldiers of that city and set out to govern Lithuania ${ }^{200}$. This source is cited deliberately for the sake of but for polemics. My failure to mention Pinsk ${ }^{201}$ (what for?) in my discussion of Lithuanian actions in this text (rather than those of Vaišelga) is called a "deliberate reworking"202. In this way the stocks of Pinsk are raised and Ermalovich needs to do this because the final sentence of this entry, albeit separated from the remainder by him $^{203}$, argues quite the opposite from what Ermalovich seeks to prove: there was no need for Lithuania to be conquered, since it welcomed Mindaugas' son ${ }^{204}$. Let us run through events in Lithuania prior to Vaišelga's accession: Mindaugas' servants had already murdered the usurper Treniota ${ }^{205}$. Naturally these were not the instigators of this action, they were obeying the orders from noble supporters of Mindaugas' family. It was a complete conspiracy and the Livonian Rhymed Chronicle mentions that the conspirators were exactly of this class and that they were Lithuanian ${ }^{206}$. The picture is complemented further by the account in the Novgorodian First Chronicle of how Mindaugas' soldiers joined Vaišelga ${ }^{207}$. This information is sonorously rejected by Ermalovich ${ }^{208}$. However, it is clear that the men of Novgorodok and Pinsk supported Vaišelga alongside the Lithuanians. The Pinsk soldiers intervened in an internal Lithuanian dispute in support of their allies. This did not amount to the conquest of Lithuania.

Such was the turn of events in Lithuania (in the narrow sense). Vaišelga still had to overcome the opposition of Deltuva and Nalšia. Here Galician intervention was decisive, but the Galicians intervened in Lithuanian affairs on one particular side. In order to raise the stocks of Galich, Ermalovich is indignant at my failure to quote the passage from Ipat'evskaia ${ }^{209}$ which relates how Vaišelga murdered

${ }^{200}$ M. Ermalovich, Po sliadakh, 1991, 78-79; PSRL, II, 1962, 861.

${ }^{201}$ E. Gudavičius, "Litva Mindovga", - Problemi etnogeneza i etnicheskoi istorii , Vilnius, 1985,220

${ }^{202}$ M. Ermalovich, Po sliadakh, 1991, 79.

${ }^{203}$ Ibid.

${ }^{204}$ PSRL, II, 1962, 861.

${ }^{205}$ Ibid.

${ }^{206} \mathrm{LR}, 164$.

${ }^{207}$ PSRL, III, 1841, 58.

${ }^{208}$ M. Ermalovich, Po sliadakh, 1991, 78.

${ }^{209}$ Ibid., 79. 
his enemies ${ }^{210}$. However, it is not incumbemt on me to quote passages which reveal nothing new concerning my theme (Lithuania). He does not notice another quotation which I give (because it is relevant to my own topic) ${ }^{211}$ which speaks even more eloquently than the one which, according to Ermalovich, I wished to pass over in silence ${ }^{212}$. Vaišelga's consolidatory actions were truly dangerous to Lithuania: he inclined towards alliance with Galich and Volyn. None denies that this was atypically opportunistic intervention in internal Lithuanian disputes by ouside parties (as the Novgorodian First Chronicle makes clear ${ }^{213}$.

Traidenis, it appears, continued Vaišelga's policies ${ }^{214}$, but he was a heathen ruler who fought fiercely against Galich and Volyn - as the Ipat'evskaia Chronicle points out ${ }^{215}$.

I will end my analysis of Ermalovich's methods of argument with the following example. The index of Nasonov's edition of the Novgorodian First Chronicle calls Gerdenis "the son of Duke David Rostislavich of Polotsk" 16 ; the Chronicle does not refer to him as such $^{217}$ and it could not do so since in the 1270s Gerdenis was an adult with young children ${ }^{218}$. He could have been born around 1220, but David Rostislavich had been sent to replace his father as prince in Novgorod in $1154^{219}$ and must therefore have been at least 20 at that time. Hence it would follow that Gerdenis was born to a father of 8090 years. This is no problem for Ermalovich when he bases his arguments of the index reference ${ }^{220}$.

Such then is the essence of this original theory of the establishment of the Belorussian state (the Grand Duchy of Lithuania). There was an elephant, but he is no more. Perhaps he never existed at all. In Fenimore Cooper's novel The Pathfinder we come across not elephants but 'two tails' - like here!

One should not forget that there is another aspect to this change in proof system. Protagoras once had a pupil who used his teacher's relativist arguments to refuse to pay for his education. So I will end with Ermalovich's own words: "you may read these words and marvel..."221

${ }^{210}$ PSRL, II, 1962, 861.

${ }^{211}$ E. Gudavičius, "Litva”, 220.

${ }^{212}$ PSRL, II, 1962, 863.

${ }^{213}$ PSRL, III, $1841,58$.

${ }^{214}$ M. Ermalovich, Po sliadakh, 1991, 81.

${ }^{215}$ PSRL, II, 1962, 869..

${ }^{216}$ Novgorodskaia pervaia letopis' starshego i mladshego izvodov, ed. A.N. Nasonov, Moscow, Leningrad, 1950, 574.

${ }^{217}$ Ibid., 85, 314, 315.

${ }^{218}$ Ibid., 85.

${ }^{219}$ Ibid., 29.

${ }^{220}$ M. Ermalovich, Po sliadakh, 1989, 78.

${ }^{221}$ Ibid., 62. 